\title{
Impact of estuarine fronts on the dispersal of piscivorous birds in the German Bight
}

\author{
Henrik Skov*, Erik Prins \\ Ornis Consult A/S, Vesterbrogade 140, 1620 Copenhagen V, Denmark
}

\begin{abstract}
Survey data on seabird distribution at sea, hydrographic data and optical satellite data collected for the German Bight were used to analyse the variability of the distribution of wintering redthroated diver and black-throated diver Gavia stellata/arctica in relation to oscillations of the Jutland Coastal Current (JCC) and associated surface fronts. Data collected from hydrographic stations were summarised by means of principal component analysis; the first component, reflecting characteristics of the JCC, provided a satisfactory quantitative measurement of the average meso-scale habitat used by both species. The pelagic range of divers clearly followed the outer estuarine front between surface North Sea water and the JCC, which was located between the 20 and $30 \mathrm{~m}$ depth contours. Despite a highly transient trailing edge of the JCC, no divers were ever observed in North Sea water. Hydrographic as well as composited satellite CZCS (Coastal Zone Color Scanner) data indicated the presence of an inner front, spanning a stronger surface salinity gradient than the outer estuarine front. The inner estuarine front was located between mixed estuarine water, with salinities between 32 and $34 \mathrm{psu}$, and the core of the estuarine water mass from the river Elbe, with salinities below $32 \mathrm{psu}$. Seven-year composite images, produced from all available CZCS-Chl (chlorophyll) data taken over the German Bight during the Nimbus-7 mission, revealed the mean distribution of the inner estuarine front as a sharp gradient between the 15 and $20 \mathrm{~m}$ depth contours, extending less than $10 \mathrm{~km}$ in longitude. The variability of the inner estuarine front was measured over a series of cruises, and it indicated a quasi-stable structure; the prevailing position of the surface front was in a zone stretching from $07^{\circ} 30^{\prime} \mathrm{E}$ at Horns Reef $\left(55^{\circ} 45^{\prime} \mathrm{N}\right)$ to $07^{\circ} 50^{\prime} \mathrm{E}$ south of Amrum Bank $\left(54^{\circ} 30^{\prime} \mathrm{N}\right)$, except during easterly winds when the front was advected offshore as far as $6^{\circ} 50^{\prime} \mathrm{E}$. The recorded patches of high densities of divers were almost confined to areas within $5 \mathrm{~km}$ distance from the mean frontal zone. The link between divers and the inner estuarine front seemed rather persistent, as peak densities coincided with the location of this front during all cruises, while lower densities were normally observed in the core Elbe water and in the mixed water outside the front. The authors suggest that the quasi-stability and strength of the inner estuarine front give rise to a predictable location of food resources (i.e. small fish) for divers in the German Bight. Our study highlights the potential for frontal structures of the JCC to influence the marine ecosystem of the southeastern North Sea.
\end{abstract}

KEY WORDS: Estuarine fronts · German Bight · Seabird foraging · Red-throated/black-throated diver • Gavia stellata/arctica

\section{INTRODUCTION}

Although the German Bight is strongly influenced by estuarine water from several large rivers, including the Elbe, knowledge of the impact of this input of riverine water on the ecosystem in the Bight is limited. Recent surveys show the presence of large numbers of pisci-

*E-mail: hs@ornisconsult.dk vorous seabirds, particularly red-throated and blackthroated divers Gavia stellata/arctica, which spend their non-breeding season in the area of estuarine impact north of the outlet of the river Elbe (Leopold et al. 1995, Skov et al. 1995). The estuarine water mass and the associated surface salinity front is generally regarded as a permanent feature which, unlike the tidal mixing front, is present throughout the year (Krause et al. 1986). The extension of river water and the position

(C) Inter-Research 2001 
of the surface front based on hydrographic measurements and model simulations seem to exhibit large variability as a function of tidal advection, weather conditions and bottom topography (Becker \& PrahmRodewald 1980, Dippner 1993a). The purpose of this paper is to address the dynamics of the aggregation of wintering divers in relation to meso- and coarse-scale features of the estuarine system by analysis of data collected over a series of cruises from 1986 to 1993, and composites of CZCS-Chl data collected over the German Bight from 1978 to 1986. Aggregations of sub-surface foraging piscivorous seabirds are commonly observed at fronts between mixed and stratified waters (Pingree et al. 1974, Schneider 1982, Kinder et al. 1983, Hémery et al. 1986, Decker \& Hunt 1996, Begg \& Reid 1997). However, only 2 studies are available on the linkage between seabird aggregations and estuarine fronts: Uspenski (1956, Novaya Zemlya) and Briggs et al. (1987, Gulf of the Farallones). As both species of divers have small biogeographic populations and suffer general declines throughout most of their European breeding range (Tucker \& Heath 1994), the identification of important wintering habitats within the estuarine system of the German Bight has become a conservation priority.

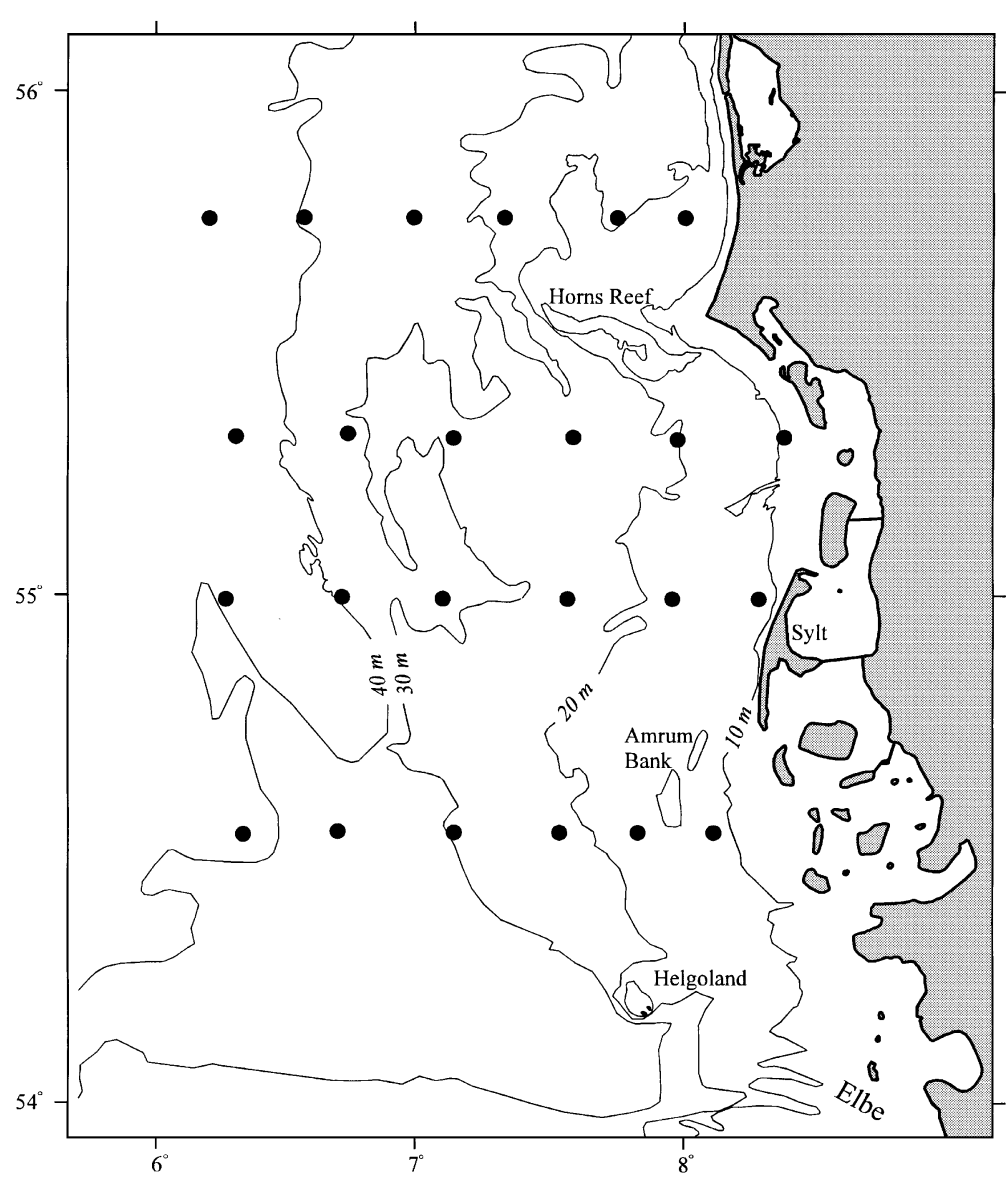

Fig. 1. Study area showing hydrographical stations monitored by RV 'Gunnar Thorson'

\section{MATERIALS AND METHODS}

Study area. The study region of the German Bight covers a surface area of $33000 \mathrm{~km}^{2}$ stretching through the German and Danish sectors of the south-eastern North Sea from $54^{\circ} 00^{\prime}$ to $56^{\circ} 00^{\prime} \mathrm{N}$ and from $6^{\circ} 00^{\prime}$ to $9^{\circ} 00^{\prime} \mathrm{E}$. Throughout the region, depth contours run parallel to the Wadden Sea; the depth of a sandy plain gradually increasing from the east to more than $40 \mathrm{~m}$ at the western extremes of the region. Offshore shallows are found at the island of Helgoland, at the Amrum Bank and at Horns Reef (Fig. 1). The discharge of freshwater from the river Elbe, which amounts to $1000 \mathrm{~m}^{3} \mathrm{~s}^{-1}$ (Dippner 1993a), and rivers further south along the east Frisian coast, affect a large area of the inner German Bight, creating an estuarine frontal system (Bowman \& Iverson 1977) that is anisotropically structured along the coastline (Frey 1990). At $54^{\circ} 00^{\prime} \mathrm{N}$ the estuarine water mass moves northwards as the Jutland Coastal Current (JCC, Lee 1980), occasionally penetrating as far as $100 \mathrm{~km}$ into the North Sea (National Danish Envi- ronmental Research Institute), and then advecting towards the Danish shoreline at $56^{\circ} 00^{\prime} \mathrm{N}$. In winter, the JCC can be distinguished from North Sea water masses by its low surface temperature, reduced water clarity and salinity below 34 psu (Lee 1980, National Danish Environmental Research Institute).

Hydrographic measurements. The principal sources of concurrent surface salinity measurements were the cruises undertaken during the Jutland Current Project of the Danish Institute for Fisheries Research (RV 'Dana') in 1986 and the annual monitoring programme of the Danish National Environmental Research Institute (RV 'Gunnar Thorson') from 1987 to 1993. Data on Secchi-depth and chlorophyll a were collected during the RV 'Gunnar Thorson' monitoring cruises.

Satellite data. The characterisation and distribution of surface water masses and the identification of the mean location of surface fronts was assisted by the use of low resolution optical satellite data for the German Bight. A total of 577 images were collected between 1978 and 1986 by the Coastal Zone Color Scanner 
(CZCS) carried onboard the Nimbus-7 mission. The entire CZCS data set is a part of the Ocean Colour European Archiving Network (OCEAN) project. The data has been fully pre-processed for application demonstration projects (level 3) on the use of pigment concentration (i.e. the concentration of chlorophyll-like pigments of phytoplankton or, more likely in this case, total suspended matter concentration) in the mapping of surface waters (from 0 to $10 \mathrm{~m}$ depth, Barale et al. 1992). The data were corrected for atmospheric interference using the algorithms of Gordon \& Clark (1981), Gordon et al. (1983) and Barale et al. (1986) and they represent a mean of all monthly composites for the period, at a resolution of $1 \times 1 \mathrm{~km}$. We processed the data using WinChips 4.1b and Idrisi for Windows 2.0, and applied a $3 \times 3$ mode filter to the data in order to obtain a more general picture. Frontal structures were classified by the analysis of gradients in CZCS-Chl along 3 longitudinal profile lines (at $54^{\circ} 30^{\prime} \mathrm{N}, 55^{\circ} 00^{\prime} \mathrm{N}$ and $55^{\circ} 30^{\prime} \mathrm{N}$ ).

Bird data. A total of 12 longer cruises (at least $200 \mathrm{~km}$ line transect) were made in the study region between April 1986 and May 1993, comprising both dedicated cruises from chartered ships and cruises from marine research ships operating in the region (Table 1). During the majority of the cruises, samples of the density of divers were taken along the entire latitudinal and longitudinal range of the study region. Except for February 1991, the sample size of count periods exceeded 100 . The data on the density of divers is considered to be relatively homogenous, as standardised methods developed specifically for recording divers at sea were applied during all cruises. Red-throated and black-throated divers are regarded as some of the more difficult birds to survey effectively at sea, from aeroplane as well as from ship (Laursen et al. 1997). Standard line transect methods for recording

Table 1. Cruise details, showing distance of transect surveyed $(\mathrm{km})$, no. of samples obtained (10 min counts) and proportion of study area covered by transect

\begin{tabular}{|lccc|}
\hline Cruise & $\begin{array}{c}\text { Distance surveyed } \\
(\mathrm{km})\end{array}$ & $\begin{array}{c}\text { No. of } \\
\text { samples }\end{array}$ & $\begin{array}{c}\text { Area covered } \\
(\%)\end{array}$ \\
\hline Apr-May 1986 & 505.4 & 112 & 0.46 \\
Oct 1986 & 474.6 & 135 & 0.43 \\
Feb 1987 & 391.4 & 183 & 0.35 \\
Oct-Dec 1987 & 1356.1 & 592 & 1.23 \\
Jan-Feb 1988 & 1415.0 & 432 & 1.28 \\
Apr-May 1988 & 763.7 & 276 & 0.69 \\
Oct-Nov 1988 & 359.2 & 119 & 0.32 \\
Feb 1991 & 242.9 & 58 & 0.22 \\
Jan-Feb 1992 & 1134.1 & 347 & 1.03 \\
Apr 1992 & 632.8 & 242 & 0.57 \\
Mar 1993 & 526.4 & 167 & 0.48 \\
May 1993 & 322.5 & 117 & 0.29 \\
& & & \\
\hline
\end{tabular}

sea birds at sea from ship as suggested by Tasker et al. (1984) have been widely accepted as a satisfactory basis for quantitative judgements of relative seabird abundance. However, modifications of the standard method are necessary to account for the reduced detectability of species such as the red- and blackthroated divers moving out of the transect as the ship approaches (Webb \& Durinck 1992). According to Tasker et al. (1984) birds in the transect should be detected by naked eye and subsequently identified and counted by the use of binoculars. Red- and blackthroated divers react strongly to approaching ships and they are only rarely detectable without the use of binoculars. In order to record the divers at the correct perpendicular distance from the transect line we used binoculars to scan the transect ahead of the ship with the assistance of an angle-distance corrector (Durinck et al. 1993). A transect width of $300 \mathrm{~m}$ was operated with 4 distance intervals $(0-50,51-100,101-200$, and 201-300 m) within a $90^{\circ}$ sector. Estimates of the density of divers per count unit $(10 \mathrm{~min})$ were made by correcting for undetected birds away from the centreline using functions of the Distance v.2.0 software package (Laake et al. 1993). The half-normal model (Buckland et al. 1993):

$$
g(x)=\exp \left(-x^{2} / 2 \sigma^{2}\right)
$$

was fitted to the distribution of perpendicular distance intervals to obtain a probability of observation of divers in transect $(p)$ and correction coefficients $(1 / p)$.

Data analysis. The strength of the average relationship between the distribution of both species of divers and the JCC was analysed by linear regression of the main gradients of the oceanographical data derived from principal component analysis and the $\log _{10^{-}}$ transformed densities of divers. As only a minority $(11.1 \%, \mathrm{n}=2756)$ of the divers was identified as either red-throated or black-throated diver and the 2 species co-occurred $\left(r_{\mathrm{s}}=0.55, \mathrm{p}<0.01\right)$, the habitat model was based on the combined abundance of the 2 species. In order to generate meso-scale patterns and reduce autocorrelation effects, the oceanographical (station) and bird density (transect segment) data were smoothed by calculating average values for $0.5^{\circ} \times$ $0.5^{\circ}$ blocks. Topographic variability was measured using the formula $\left(D_{\max }-D_{\min }\right) / D_{\max }$, where $D_{\max }$ and $D_{\min }$ are maximum and minimum depths, respectively. Salinity gradient was measured by $\left(S_{\max }-S_{\min }\right)$, where $S_{\max }$ and $S_{\min }$ are maximum and minimum salinity at the surface. A more detailed description of the relationship was made by comparing the average distribution of surface water masses and surface fronts derived from the historical CZCS-Chl data and the average distribution of divers. Densities of divers were interpolated linearly at a resolution of $3 \times 3 \mathrm{~km}$. 


\section{RESULTS}

\section{Diver affinity for estuarine water mass}

The principal component analysis of the major gradients in the geophysical variables of the German Bight summarised the variables into 3 main factors accounting for $85 \%$ of the standardised variation (Table 2). The first principal component, which accounted for $52 \%$ of the variance, combined shallow areas $<20 \mathrm{~km}$ from the coast with water masses of low surface temperature, salinity and water clarity, strong salinity gradients, and a relatively high density of chl a. These characteristics reflect the oceanographic environment of the JCC well (Karup 1993), while the second and the third components mainly reflected characteristics of North Sea water masses. A strong average relationship was indicated between the density of wintering divers and the averaged eigenvalues of the first principal component. The equation of the regression line between PCA1 and $\log _{10}$ diver density was $y=0.22+0.06 x$ $(\mathrm{r}=0.85, \mathrm{p}<0.01)$. The affinity for the JCC was further underlined by the fact that no divers were recorded in waters with a surface salinity above $34 \mathrm{psu}$.

\section{Importance of coarse scale features}

The time series of hydrographic measurements from RV 'Gunnar Thorson' shows that an increasing eastwest gradient in surface salinity was present during all surveys (Fig. 2). The estuarine water mass can be compartmentalised into an inner zone of salinities below

Table 2. Results of the principal component analysis of oceanographic variables in the south-eastern North Sea, north of the river Elbe. Surface water characteristics refer to samples taken during the February cruises by RV 'Gunnar Thorson' from 1987 to 1990. Eigenvectors of the first 3 components are shown, together with the proportion and cumulative percentage of the standardised variance accounted for

\begin{tabular}{|lrrr|}
\hline Variable & PC 1 & PC 2 & PC 3 \\
\hline Large distance from the coast $(\geq 20 \mathrm{~km})$ & -0.31 & -0.02 & 0.25 \\
Sand bottom & -0.01 & 0.59 & -0.30 \\
High chl a values $\left(\geq 1.0 \mathrm{mg} \mathrm{l}^{-1}\right)$ & 0.40 & 0.06 & -0.03 \\
Shallow water $(<20 \mathrm{~m})$ & 0.36 & 0.09 & -0.31 \\
Medium water depth $(20-40 \mathrm{~m})$ & -0.06 & 0.49 & 0.53 \\
Deep water $(\geq 40 \mathrm{~m})$ & -0.23 & -0.51 & -0.24 \\
High topographic variability $(\geq 0.5)$ & 0.28 & 0.29 & 0.15 \\
High water clarity $(\geq 4 \mathrm{~m})$ & -0.32 & 0.08 & 0.42 \\
Low surface temperature $\left(<2.0^{\circ} \mathrm{C}\right)$ & 0.37 & -0.03 & 0.22 \\
Low surface salinity $(<33 \% \mathrm{~S})$ & 0.37 & -0.043 & 0.22 \\
Strong salinity gradient $(\geq 1.0 \% \mathrm{~S})$ & 0.32 & -0.21 & -0.34 \\
Proportion $(\%)$ & 52 & 19 & 14 \\
Cumulative $(\%)$ & 52 & 71 & 85 \\
\hline
\end{tabular}

32 psu and an outer zone of salinities between 32 and 34 psu (Fig. 2). The location of the boundary between the outer zone of mixed estuarine water and North Sea water ( $>34 \mathrm{psu}$ ) varied considerably. The outer estuarine front was generally located between the 20 and $30 \mathrm{~m}$ isobaths. The mean transition between the low saline compartment and the zone of mixed estuarine water was marked by a stronger surface salinity gradient than the outer estuarine front, and was located between the 15 and the $20 \mathrm{~m}$ isobars. The front was recorded along the 3 southern transects in a limited region around $07^{\circ} 30^{\prime} \mathrm{E}$, except for during the survey in 1987, which was dominated by easterly winds. The demarcation of the inner estuarine front varied along the northern transect north of Horns Reef, and was found west of $07^{\circ} 30^{\prime} \mathrm{E}$ in 1989 and 1991, and generally appeared to be weaker than that recorded south of the reef. The historical CZCS-Chl measurements clearly indicated that the lateral extension of the mean inner estuarine surface front spanned the gradient between 1.50 and $1.55 \mathrm{mg} \mathrm{m}^{-3}$ chlorophyll-like pigment (Fig. 3). The mean gradient formed a sharp, $10 \mathrm{~km}$ wide, southnorth wedge stretching from $07^{\circ} 30^{\prime} \mathrm{E}$ at Horns Reef $\left(55^{\circ} 45^{\prime} \mathrm{N}\right)$ to $07^{\circ} 50^{\prime} \mathrm{E}$ south of Amrum Bank $\left(54^{\circ} 30^{\prime} \mathrm{N}\right)$ (Fig. 3a). The outer estuarine front, on the other hand, was not apparent in the mean CZCS-Chl measurements.

The mean density of divers varied along a west-east gradient, with densities increasing rapidly from nil in North Sea water masses to $>1$ bird $\mathrm{km}^{-2}$ just inside the outer estuarine front. Higher density patches ( $>3$ birds $\mathrm{km}^{-2}$ ) were almost confined to areas within a distance of $5 \mathrm{~km}$ from the mean inner estuarine front (Fig. 3b). Densities exceeding 10 birds $\mathrm{km}^{-2}$ were associated with the segments of the inner front overlapping the shallows at Horns Reef and Amrum Bank as well as an area off Sylt.

\section{DISCUSSION}

\section{Variability of estuarine fronts}

This study on the variability of wintering divers in relation to meso- and coarse-scale features of the JCC has provided strong indications for a coarse-scale permanent twin-frontal estuarine system. The system includes a transient outer estuarine front and a stronger, quasi-stable inner front, which both clearly influence the distribution of the study species. Dippner's (1993a) simulations of the meso-scale variability of the German Bight showed that the dynamics of the outer estuarine front mainly depends on wind forcing. The outer front may oscillate over $O(10 \mathrm{~km})$ on a time scale of $O(10 \mathrm{~h})$. Our observations, which showed that 

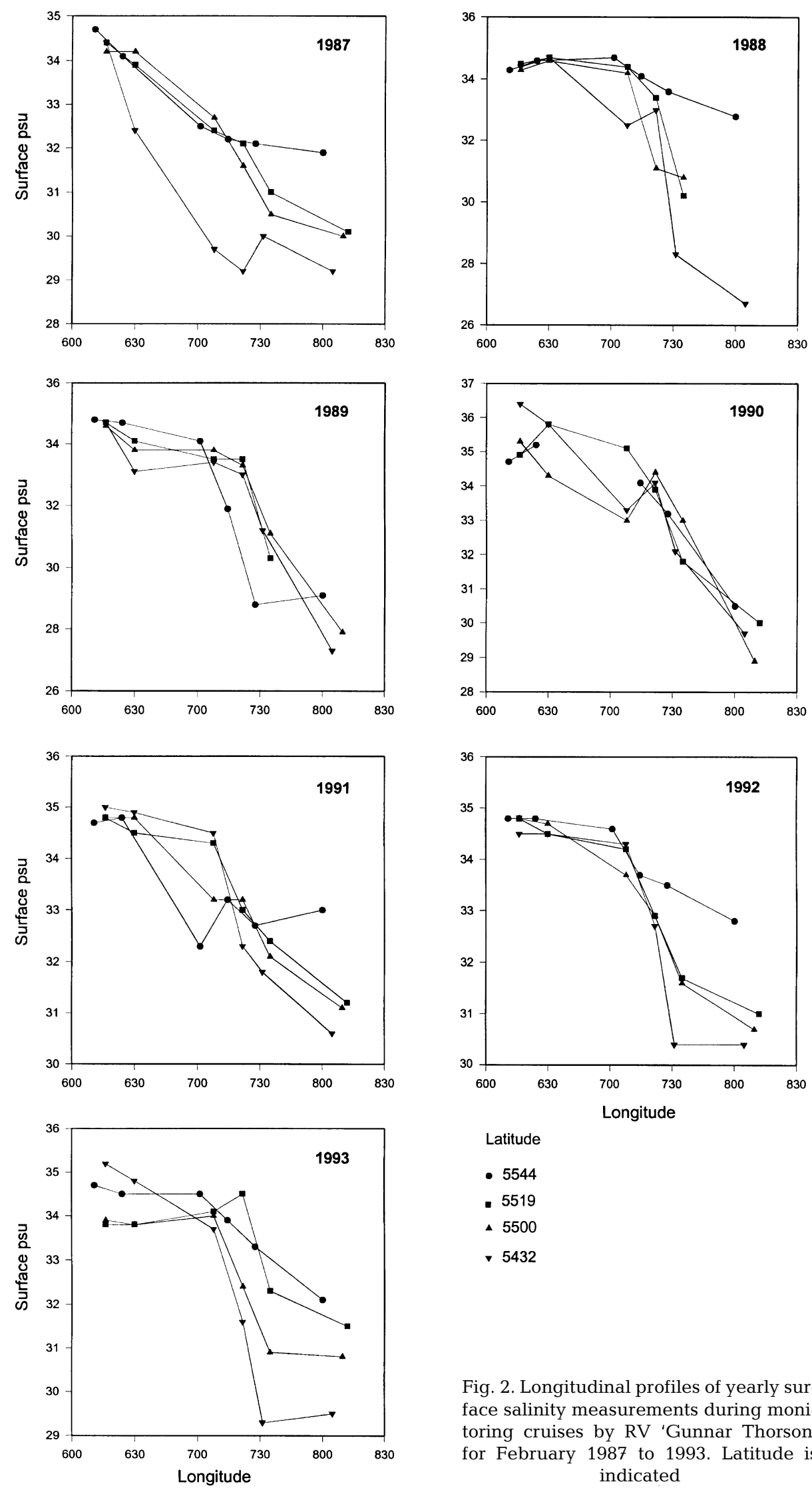

$$
\begin{aligned}
& \text { Latitude } \\
& \text { - } 5544 \\
& \text { - } 5519 \\
& \text { - } 5500 \\
& \text { - } 5432
\end{aligned}
$$

Fig. 2. Longitudinal profiles of yearly surface salinity measurements during monitoring cruises by RV 'Gunnar Thorson' for February 1987 to 1993. Latitude is indicated 

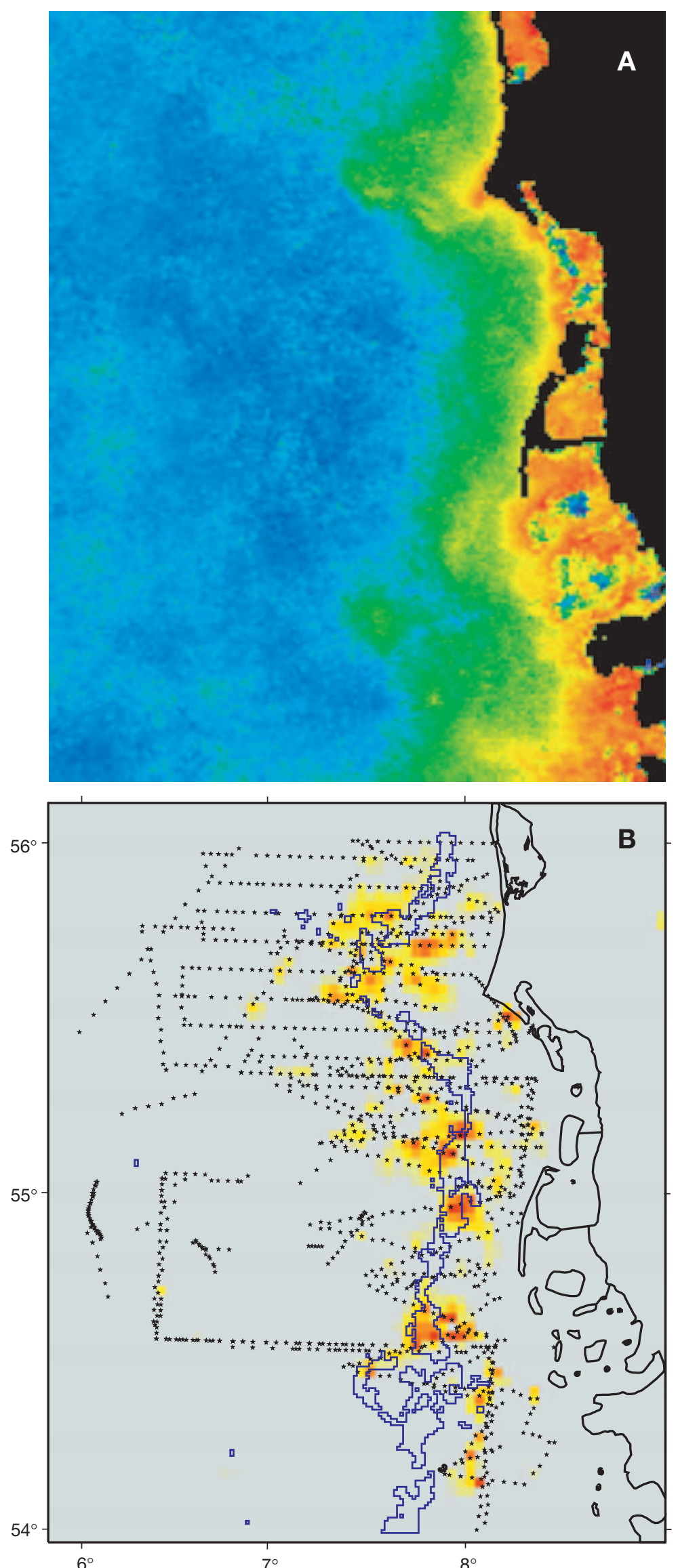

$6^{\circ}$ $7^{\circ}$
Chl a $\left(\mathrm{mg} \mathrm{m}^{-3}\right)$
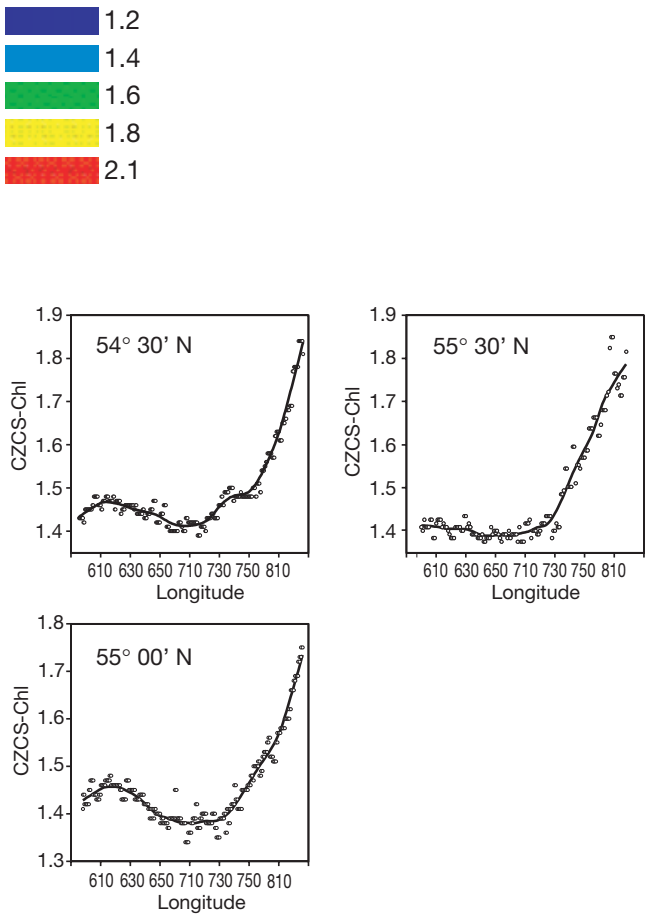

Mean frontal zone

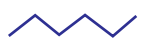

Survey effort

Survey

Fig. 3. 7-year mean CZCS-Chl for (a) the German Bight and (b) estimated mean winter density of redthroated and black-throated diver. (a) includes 3 longitudinal profiles of mean CZCS-Chl measurements. Smoothed (LOWESS) profiles are indicated by solid lines. (b) includes an indication of the mean range of the inner estuarine front 
the position of the front varied between the 20 and $30 \mathrm{~m}$ depth contours, and that the front does not appear in the mean CZCS-Chl data, underline the dynamic nature of this front.

Knowledge of the dynamics of the inner front is poor compared with the outer estuarine front. We interpret the high degree of overlap between the mean frontal zone, indicated by the CZCS images, and the position of the front recorded during all cruises made in westerly winds (between the 15 and $20 \mathrm{~m}$ depth contours) as an indication that under the prevailing winter conditions in the German Bight, the inner front has a rather predictable east-west configuration. Judging from the circulation pattern and salinity distribution, the water mass inside the inner front may be characterised as the core of the Elbe plume, and the water mass outside this front as a mixture of water from the Elbe and water originating from rivers further south. Consequently, the front represents a strong hydrographic gradient. As our observations were made during relatively calm conditions and the satellite images have a weather-dependent bias against cloudy conditions, it is likely that the salinity gradient and the predictable configuration of the inner front may not be present during strong cyclonic conditions.

\section{Meso- and coarse-scale habitat affinities}

Interpretation of the ordination of physical oceanographic data was relatively clear and provided a satisfactory meso-scale expression of the JCC (PC 1) and the water masses of the North Sea (PC 2 and PC 3) during the winter season. The average relationship between the distribution of wintering red- and blackthroated divers and the distribution of the JCC proved rather strong, with the first principal component providing a good model of the average distribution of divers, accounting for $73 \%$ of the variance. The fact that divers were not recorded in water masses of the North Sea during any of the cruises further underlines the affinity of divers for the estuarine water mass.

The tendency for peak densities of divers to be found at the inner front was rather strong, and the limited amount of deviation from this tendency, as illustrated by the average fine-scale pattern in Fig. 3, discounts the possibility of randomly coinciding patterns. Bathymetry seems to be of secondary importance as a determinant of the habitat of the wintering divers. Although the eastern part of the German Bight is relatively shallow compared to most parts of the North Sea, and local high densities of divers were observed at the banks, peak densities were not associated with the shallowest easterly inner section of the German Bight. Despite the ubiquitous occurrence and easy accessibility of estuar- ine fronts, few studies have been carried out on their biological importance. These studies do, however, indicate that enhanced secondary production of plankton and fish should be expected at estuarine fronts (Tsujita 1957, Owen 1968, Pearcy \& Keene 1974, Tyler \& Seliger 1978, Krause et al. 1986). We suggest that frontal processes at the inner front in the German Bight may increase the availability of the primary prey of wintering divers, i.e. small fish < 25 g (Madsen 1957, Durinck et al. 1994a). The diet of the 2 species in Danish waters consists of a wide range of pelagic as well as bottom-dwelling species such as herring Clupea harengus, sprat Sprattus sprattus, cod Gadus morhua, whiting Merlangius merlangus and sticklebacks Gasterosteus spp. (Madsen 1957, Durinck et al. 1994a).

The frequent observations of seabird aggregations at oceanographic fronts and in regions of seasonal upwelling indicate intensive usage of recurring patches of prey (Schneider 1990). We suggest that in a given climatic scenario, quasi-stable processes governed by the inner front in the German Bight create a predictable location of abundant prey fish for divers in the JCC. The 2 species of divers studied are relatively large birds (1.0 to $3.5 \mathrm{~kg}$, Cramp \& Simmons 1977) that experience large energy costs related to flying. Predictability of prey may therefore be a key factor explaining their strong association with a predictable element of the JCC estuarine system. Predictability may be an important element of seabirds' dependence on frontal features in general, a notion which is consistent with the evidence of large increases in the density of seabirds (from $<10$ birds $\mathrm{km}^{-2}$ to $>1000$ birds $\mathrm{km}^{-2}$ ) on both sides of tidal mixing fronts (Schneider 1982, Begg \& Reid 1997). The strength of the inner estuarine front may be an equally important characteristic determining its biological importance in the German Bight. The impact of the strength of surface gradients on the distribution of seabirds has only been studied in the southeastern Bering Sea, where Schneider et al. (1987) found the attendance of birds to peak at fronts characterised by strong surface flow.

Fine-scale process-oriented studies are needed to resolve the linkage between the area swept by the inner estuarine front and enhanced prey abundance. Modelling of fine-scale transient eddies at the Elbe plume front shows that during westerly winds, 3 eddies develop in bottom waters inside the $20 \mathrm{~m}$ depth contour at the southern edge of Horns Reef, Amrum Bank and off Sylt (Dippner 1993b, 1998). The development of these eddies seems to be coincident with a higher survival index for sprat larvae during westerlies in the German Bight. This effect can be explained by the combined effect of surface transport into the German Bight and the breakdown of northward circulation created by the eddy field in the deeper layers (Dippner 
1993b). Our study did not permit analysis of diver distribution in relation to the development of eddies in the German Bight, but the observed high densities of divers at Horns Reef, Amrum Bank and off Sylt ( $>10$ birds $\mathrm{km}^{-2}$ ) suggest that the eddy field comprises an important habitat element for the divers.

\section{CONCLUSION}

Our results point unambiguously towards the ecological importance of frontal structures of the JCC in relation to the marine ecosystem of the southeastern North Sea. The results confirm that large estuarine systems can support smaller scale structural heterogeneity, as indicated by Dippner (1993b), and they show that the more predictable and stronger frontal features of the system have the potential to sustain concentrations of predators over extended periods of time. Both the red-throated and black-throated divers wintering in the German Bight are recruited from the Fennoscandian and Russian populations that spend their non-breeding season in shelf seas such as the North Sea and the Baltic Sea (Cramp \& Simmons 1977, Ilicev 1985, Durinck et al. 1994b, Skov et al. 1995). As the occurrence of divers in the German Bight represents one of the largest known winter concentrations of both species along this fly-way (more than 24000 birds; Skov et al. 1995), the inner estuarine front may be regarded as a key habitat feature for these species.

Acknowledgements. The National Danish Environmental Research Institute and the Danish Institute for Fisheries Research are acknowledged for the hydrographic information provided for this study and for their kind co-operation during the cruises of RV 'Gunnar Thorson' and RV 'Dana'. Special thanks goes to Joachim W. Dippner, of the Max-Planck-Institute for Meteorology, and Gunni Ærtebjerg, of the National Danish Environmental Research Institute, who commented on an earlier draft of the manuscript. The survey work was funded by Mærsk Oil and Gas, The Commission of the European Union, The Danish National Forest and Nature Agency, Netherlands Institute for Sea Research, World Wide Fund for Nature Sweden and The Scientific Committee of the Danish Ornithological Society.

\section{LITERATURE CITED}

Barale V, McClain CR, Malanotte-Rizzoli P (1986) Space and time variability of the surface color field in the northern Adriatic Sea. J Geophys Res 91:12957-12974

Barale V, Schlittenhardt PM, Fusco L (1992) Programmes for optical remote sensing of the European marine environment. In: Eger $\mathrm{H}$ (ed) Proceedings of the Central Symposium of the 'International Space Year' Conference, Munich, 30 Mar-4 Apr 1992. ESA ISY-1 Vol III, p 1263-1267
Becker GA, Prahm-Rodewald G (1980) Fronten im Meer. Salzgehaltsfronten in der Deutschen Bucht. Seewart 41: $12-21$

Begg GS, Reid JB (1997) Spatial variation in seabird density at a shallow sea tidal mixing front in the Irish Sea. ICES J Mar Sci 54:552-565

Bowman MJ, Iverson RL (1977) Estuarine and plume fronts. In: Bowman MJ, Esaias WE (eds) Oceanic fronts and coastal processes. Proc Workshop Mar Science Res Center, May 1977. Springer-Verlag, Berlin, p 87-104

Briggs KT, Tyler WB, Lewis DB, Carlson DR (1987). Bird communities at sea off California: 1975-1983. Avian Biol 11: $1-74$

Buckland ST, Anderson DR, Burnham KP, Laake JL (1993) Distance sampling: estimating abundance of biological populations. Chapman \& Hall, London

Cramp C, Simmons E (1977) The birds of the Western Palearctic, Vol 1. Oxford University Press

Decker MB, Hunt GL Jr (1996) Foraging by murres (Uria spp.) at tidal fronts surrounding the Pribilof Islands, Alaska, USA. Mar Ecol Prog Ser 139:1-10

Dippner JW (1993a) A frontal-resolving model for the German Bight. Cont Shelf Res 13:49-66

Dippner JW (1993b) Larvae survival due to eddy activity and related phenomena in the German Bight. J Mar Syst 4: 303-313

Dippner JW (1998) Vorticity analysis of transient shallow water eddy fields at the river plume front of the River Elbe in the German Bight. J Mar Syst 14:117-133

Durinck J, Skov H, Andell P (1993) Seabird distribution and numbers in selected offshore parts of the Baltic Sea, winter 1992. Ornis Svec 3:11-26

Durinck J, Skov H, Danielsen F, Christensen KD (1994a) Winter food of red-throated diver Gavia stellata in the Skagerrak. Dansk Orn Foren Tidsskr 88:39-41 (in Danish with English summary)

Durinck J, Skov H, Jensen FP, Pihl S (1994b) Important marine areas for wintering birds in the Baltic Sea. EU DG XI research contract no. 2242/90-09-01. Ornis Consult report

Frey H (1990) Stratification during periods of oxygen deficiency in the German Bight during the summers from 1981 to 1983: a comparison with the long-term variation in stratification. Meeresforschung 32:306-328

Gordon HR, Clark DK (1981) Clear water radiances for atmospheric correction of coastal zone color scanner imagery. Appl Optics 20:4175-4180

Gordon HR, Clark DK, Brown JW, Brown OB, Evans RH, Broenkow WW (1983) Phytoplankton pigment concentrations in the Middle Atlantic Bight: comparisons between ship determinations and Coastal Zone Color Scanner estimates. Appl Optics 22:20-36

Hémery G, Pasquet E, Yesou P (1986) Data banks and population monitoring in France. In: Medmaravis, Monbailliu X (eds) Mediterranean marine avifauna: population studies and conservation. Springer-Verlag, Berlin, p 163-177

Illicev VD (1985) Handbuch der Vögel der Sowjetunion, Vol 1, Wittenberg Lutherstadt, Ziemsen

Karup H (1993) North Sea subregion 5 assessment report 1993. Danish Environmental Protection Agency, Ministry of the Environment, Copenhagen

Kinder TH, Hunt GL Jr, Schneider D, Schumacher JD (1983) Correlations between seabirds and oceanic fronts around the Pribilof Islands, Alaska. Estuar Coast Shelf Sci 16: 309-319

Krause G, Budeus G, Gerdes G, Schaumann K, Hesse K 
(1986) Frontal systems in the German Bight and their physical and biological effects. In: Nihoul JCJ (ed) Marine interfaces ecohydrodynamics. Elsevier Oceanography Series 42, Elsevier, Amsterdam, p 119-140

Laake JL, Buckland ST, Anderson DR, Burnham KP (1993) DISTANCE User's Guide v2.0. Colorado Cooperative Fish \& Wildlife Research Unit, Colorado State University, Fort Collins, $\mathrm{CO}$

Laursen K, Pihl S, Durinck J, Hansen M, Skov H, Frikke J, Danielsen F (1997). The numbers and distribution of waterfowl in Denmark 1987-1989. Dan Rev Game Biol 15(1):1-181

Lee AJ (1980) North Sea: physical oceanography. In: Banner FT, Collins MB, Massie KS (eds) The sea and the sea bed in motion. Elsevier Oceanography Series 24B, Elsevier, Amsterdam, p 467-493

Leopold MF, Skov H, Durinck J (1995) The distribution and numbers of red-throated divers Gavia stellata and Blackthroated Divers Gavia arctica in the North Sea in relation to habitat characteristics. Limosa 3:125

Madsen FJ (1957) On the food habits of some fish-eating birds in Denmark. Dan Rev Game Biol 3(2):19-83

Owen RW (1968) Oceanographic conditions in the northeast Pacific and their relation to the albacore fishery. Fish Bull 66:503-526

Pearcy WG, Keene DF (1974) Remote sensing of water colour and sea surface temperatures off the Oregon coast. Limnol Oceanogr 6:164-180

Pingree RD, Forster GR, Harrison GK (1974) Turbulent convergent tidal fronts. J Mar Biol Assoc UK 54:469-479

Editorial responsibility: Otto Kinne (Editor),

Oldendorf/Luhe, Germany
Schneider DC (1982) Fronts and seabird aggregations in the southeastern Bering Sea. Mar Ecol Prog Ser 10:101-103

Schneider DC (1990) Seabirds and fronts - a brief overview. Polar Res 8:7-22

Schneider DC, Harrison NM, Hunt GL Jr (1987) Variation in the occurrence of marine birds at fronts in the Bering Sea. Estuar Coast Shelf Sci 25:135-141

Skov H, Durinck J, Leopold MF, Tasker ML (1995) Important bird areas for seabirds in the North Sea, including the Channel and Kattegat. BirdLife International, Cambridge

Tasker ML, Jones PH, Dixon TJ, Blake BF (1984) Counting seabirds at sea from ships: a review of methods employed and a suggestion for a standardised approach. Auk 101: $567-577$

Tsujita T (1957) The fisheries oceanography of the east China Sea and Tsuchima Strait. The structure and ecological character of the fishing grounds. Bull Seikai Reg Fish Lab 13:1-47

Tucker GM, Heath MF (1994) Birds in Europe: their conservation status. BirdLife International, Cambridge

Tyler MA, Seliger HH (1978) Annual subsurface transport of a red tide dinoflagellate toits bloom area: water circulation patterns and organism distributions in the Chesapeake Bay. Limnol Oceanogr 23:227-246

Uspenski SM (1956) The bird bazaars of Novaya Zemlya. Translated by Canadian Wildlife Service, Ottawa, 1958

Webb A, Durinck J (1992) Counting birds from ship. In: Komdeur J, Bertelsen J, Cracknell G (eds) Manual for aeroplane and ship surveys of waterfowl and seabirds. IWRB Spec Publ 19:24-37

Submitted: April 28, 1999; Accepted: October 26, 2000 Proofs received from author(s): April 16, 2001 